\title{
Batch technique to evaluate the efficiency of different natural adsorbents for defluoridation from groundwater
}

\author{
Pankaj Kumar $^{1,2} \cdot$ Chitresh Saraswat $^{1} \cdot$ Binaya Kumar Mishra $^{1} \cdot$ Ram Avtar $^{1}$ • \\ Hiral Patel ${ }^{2} \cdot$ Asha Patel $^{2} \cdot$ Tejal Sharma ${ }^{2} \cdot$ Roshni Patel $^{2}$
}

Received: 19 June 2015/ Accepted: 1 September 2016/Published online: 21 September 2016

(c) The Author(s) 2016. This article is published with open access at Springerlink.com

\begin{abstract}
Fluoride pollution (with concentration $>1.0 \mathrm{mg}$ / L) in groundwater has become a global threat in the recent past due to the lesser availability of potable groundwater resource. In between several defluoridation techniques discovered so far, the adsorption process proved to be most economic and efficient. This study is an effort to evaluate defluoridation efficiency of powdered rice husk, fine chopped rice husk and sawdust by the batch adsorption process. Optimum defluoridation capacity is achieved by optimizing various parameters, viz. dose of adsorbent, $\mathrm{pH}$, contact time and initial concentration. It was found that all three materials can be employed for the defluoridation technique, but powdered rice husk is the best adsorbent in the midst of all three. Powdered rice husk showed fluoride removal efficiency ranging between 85 and $90 \%$ in the contact period of $7 \mathrm{~h}$ only in conditions of all optimized parameter. Following this parameter optimization, adsorption efficiency was also evaluated at natural $\mathrm{pH}$ of groundwater to minimize the cost of defluoridation. No significant difference was found between fluoride adsorption at optimized $\mathrm{pH}(\mathrm{pH}=4)$ and natural one $(\mathrm{pH}=7)$, which concludes that powdered rice husk can be efficiently used for the defluoridation technique at field scale. The adsorption isotherm using this adsorbent perfectly followed Langmuir isotherms. The value of calculated separation
\end{abstract}

Pankaj Kumar

pankajenvsci@gmail.com

1 Institute for the Advanced Study of Sustainability (UNUIAS), United Nations University, 5-53-70, Shibuya-Ku, Tokyo 150-8925, Japan

2 Institute of Science and Technology for Advance Studies and Research (ISTAR), Vallabh Vidyanagar, Gujarat 388120, India factor also suggests the favourable adsorption of fluoride onto this adsorbent under the conditions used for the experiments. The field application for defluoridation of groundwater using this adsorbent (based on $\mathrm{pH}$ of natural groundwater there and seasonal variation of temperature) showed the high success rate.

Keywords Adsorption - Fluoride pollution - Groundwater quality · Powdered rice husk · Fine chopped rice husk · Saw dust

\section{Introduction}

Fluoride is a normal constituent of natural water because of its high reactivity. Normally, fluorine exists in the form of fluoride in natural waters (Leung and Hrudey 1985). Its concentration, though, varies significantly depending on the water source. Although both geological and manmade sources contribute to the occurrence of fluoride in water, the major contribution comes from geological sources like presence of fluoride-rich minerals (Kumar et al. 2016). The most common fluoride-containing minerals are fluorspar, cryolite, muscovite, biotite, fluorite and fluorapatite (Avtar et al. 2013). Along with the geological and mineralogical signature of the aquifer matrix, other physico-chemical characteristics of the aquifer such as porosity and alkalinity of the soil and rocks, temperature, chemical reaction of coexisting ions and the depth of wells also play a contributing role for release of fluoride in groundwater. In India, fluoride is the major inorganic pollutant of natural origin found in groundwater and, due to large number of variables, the fluoride concentrations in groundwater range from well under $1.0 \mathrm{mg} / \mathrm{L}$ to more than $35.0 \mathrm{mg} / \mathrm{L}$ (IPCS 1984; 
Kumar et al. 2016). From human health perspectives, fluoride helps in the normal mineralization of bones and formation of dental enamel (Cao et al. 2000; Rajkumar et al. 2015). The total daily intake of fluoride from food is about $0.2-0.5 \mathrm{mg}$ which is about only $10-15 \%$ of the required dose and hence we have to be dependent on groundwater to fulfil this deficit (Boyle and Chagnon 1995). The desirable safe limit of fluoride in drinking water is $1.0 \mathrm{mg} / \mathrm{L}$ (WHO 1984). In case the daily intake of fluoride is low (i.e. $<0.5 \mathrm{mg} / \mathrm{L}$ ), various health issues may occur, viz. dental caries, lack of formation of dental enamel and deficiency of mineralization of bones, especially affecting children (Ingle et al. 2014). On the other hand, excess daily intake of fluoride (i.e. $>1.5 \mathrm{mg} / \mathrm{L}$ ) also causes several health-related problems, viz. fluorosis affecting all age group people (Mondal et al. 2009). When fluoride is consumed in the range of $1.5-2.0 \mathrm{mg} / \mathrm{L}$, dental fluorosis or dental mottling may occur, characterized by brown or black opaque patches on the enamel/tooth surface (Kharb and Susheela 1994). Intake of fluoride exceeding $3.0 \mathrm{mg} / \mathrm{L}$ for a longer period of time results in skeletal fluorosis characterized by deformation of bones (Goldman et al. 1991). Other than the above-mentioned diseases, excessive intake than the recommended limit of fluoride may lead to increased thirst, skin rashes, muscle fibre degeneration, blood cell deformation, gastrointestinal problems, urinary tract malfunctioning, and overall reduced immunity(Meenakshi and Maheshwari 2006; Singh et al. 2011). At the global scale, higher concentrations of fluoride (i.e. $>1.5 \mathrm{mg} / \mathrm{L}$ ) in groundwater and related health effects is well reported in more than 30 countries, namely China, Syria, Jordan, Ethiopia, Sudan, Tanzania, Kenya, and Uganda (Ando et al. 2001; Razbe et al. 2006). In the case of India, groundwater contamination with fluoride is well reported at numerous places in the states of Andhra Pradesh, Gujarat, Karnataka, Madhya Pradesh, Rajasthan, Chhattisgarh, Haryana, Orissa, Punjab, Haryana, Uttar Pradesh West Bengal, Bihar, Delhi, Jharkhand, Maharashtra, and Assam (Keshari and Dhiman 2001; Jacks et al. 2005; CGWB 2010). In Gujarat, the Government of India has highlighted Mehsana District in particular as a water quality concern area with specific reference to fluoride enrichment. Many studies reveal that infants, children and adults in Mehsana District are exposed to high doses of fluoride from groundwater (Chinoy et al. 1992; Dhiman and Keshari 2003).

The fluoride contamination and its removal approach attract a lot of concern from the scientific community at the global scale due to finite potable groundwater resource. The main traditional techniques used by the scientific community for defluoridation are ion exchange, immobilization, electrodeposition, membrane separation, precipitation and adsorption. Amidst these techniques, adsorption is a widely accepted method for defluoridation because of its ease of operation as well as economic feasibility (Ingle et al. 2014). Chidambaram et al. (2013) gave a detail literature review for the different adsorption materials (both natural and synthetic) used for defluoridation from groundwater. Along with that, some of the adsorbents used recently are microwave-assisted activated carbon (Dutta et al. 2012), physicochemically treated sand (Togarepi et al. 2012), pumice (Malakootian et al. 2011) and raw bauxite (Sajidu et al. 2012). The most commonly reported adsorbents are activated alumina and activated carbon. However, treatment and disinfection of water for drinking purpose using available mitigation approaches make it too expensive and complex for application in poor communities.

As mentioned above, although there are few scientific publications targeting defluoridation by natural adsorbent, targeting adsorbent on its availability and affordability is still very sparse and more attention needs to be paid. Therefore, in this study an effort is made to observe the adsorption of fluoride from groundwater of Mehsana District, Gujarat, India, on finely chopped rice husk, powdered rice husk and sawdust. These adsorbents are also chosen on the basis of availability (very commonly available) as well as affordability (very cheap) with local residents there.

\section{Study area}

Mehsana District of Gujarat is located between $23^{\circ} 15^{\prime}$ and $23^{\circ} 53^{\prime} \mathrm{N}$ latitudes and $72^{\circ} 07^{\prime}$ and $72^{\circ} 26^{\prime} \mathrm{E}$ longitude and shares a common border with Patan District (Fig. 1). It has a total geographical area of $4393 \mathrm{~km}^{2}$ which is divided into nine subsections called talukas. The climate of the area is warm, sub-humid, sub-tropical and monsoonal. The month of May is generally the hottest and January is considered the coldest. The mean, maximum and minimum temperature is 27,45 and $15{ }^{\circ} \mathrm{C}$, respectively. The mean annual rainfall is $600 \mathrm{~mm}$ and about $93.5 \%$ of the total rainfall is received during the month of June to September by the south-west monsoon and maximum rainfall is received during the month of July and August. The area is intersected by numerous streams, namely Sabarmati, Rupen, Saraswati, Khari, and Pushpawati. The geomorphology of the area is almost monotonously flat and featureless and is represented by alluvial plain.

\section{Sampling and analytical techniques}

Based on the consumer's health issues recorded as shown in (Fig. 2), a total of 34 samples were collected from the study area. Most of the groundwater samples were collected from tube wells. The sample coordinates were 


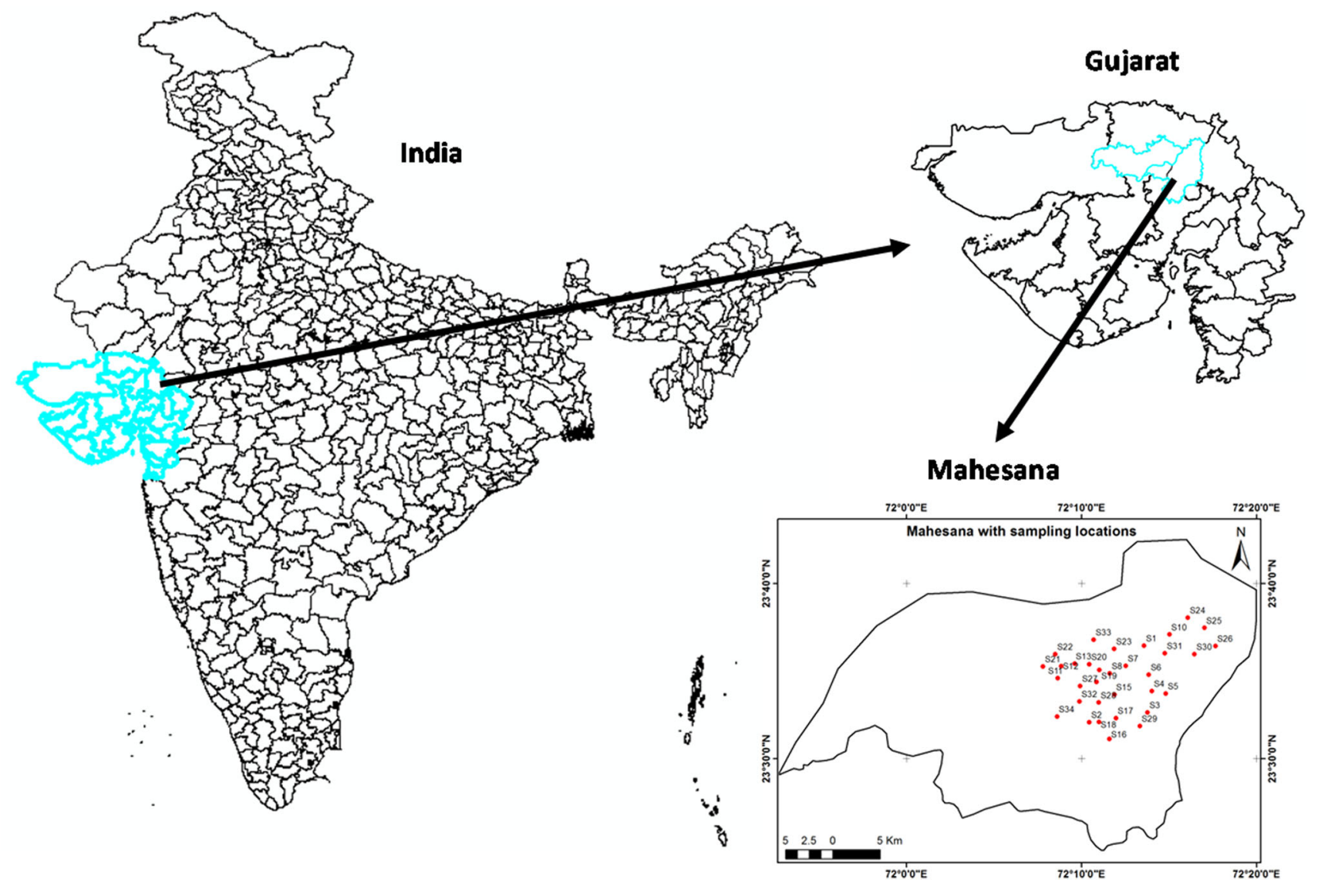

Fig. 1 Study area map showing sampling location

recorded using the global positioning system (GPS III, Garmin). Groundwater samples were collected using clean polyethylene bottles, and water samples were collected after pumping the water for 5-10 min. Following the collection, samples were brought to the laboratory in an ice chest and stored at below $4{ }^{\circ} \mathrm{C}$ for fluoride analysis. Fluoride was analysed by the SPANDS method using the Jenway model 6505 spectrophotometer (APHA 1995), and high-purity reagents (Merck) and Milli-Q water (Model Milli-Q, Biocel) were used for all the analysis. Analytical reagent-grade sodium fluoride $(\mathrm{NaF})$, SPADNS reagent $(4$, 5-dihydroxy-3-(P-sulfophenylazo)-2, 7-naphthalene-disulfonic acid trisodium salt), zirconium oxychloride, concentrated $\mathrm{HCl}$, and distilled water were used in the analysis of fluoride. A stock solution of fluoride was prepared by dissolving sodium fluoride in distilled water and working fluoride solution of different concentrations were prepared from stock fluoride solution by appropriate dilution.

All the experiments of batch adsorption are piloted to examine the effect of various parameters like dose of adsorbent, $\mathrm{pH}$ of working media, initial concentration of fluoride in the working sample, and contact time for which the adsorbent was kept in the working media. All experiments are conducted in a closed chamber at constant background room temperature of $25 \pm 2{ }^{\circ} \mathrm{C}$ measured with laboratory-installed thermometer. During the whole reaction time, the conical flask was kept on a shaker with constant speed at $130 \mathrm{rpm}$ (rotations per minute). On completion of reaction time, the adsorbate is separated from the solution using Whatman filter paper No. 42 and the filtrate is analysed for residual fluoride concentration using the SPADNS method. A known weight of adsorbent material is added into $50 \mathrm{~mL}$ of prepared samples of fluoride taken in a conical flask.

The effect of adsorbent dose on defluoridation is calculated by adding $0.5,1,2,3,4,5$ and $10 \mathrm{~g}$ of the adsorbent in a working solution of known concentration $(5 \mathrm{mg} /$ L) taken in seven different flasks. After $10 \mathrm{~h}$ of reaction time, the fluoride concentration is measured. The fluoride adsorption from solution is strongly influenced by the $\mathrm{pH}$ of the working solution and the effect of the $\mathrm{pH}$ of the working solution on fluoride adsorption is studied by adjusting the $\mathrm{pH}$ of the working solution from $\mathrm{pH} 4.0$ to 8.0. The initial concentration of the targeted pollutant also has remarkable effect on its removal by adsorption. Thus, samples of different fluoride concentrations $(2,5,10,15$, 20,25 and $50 \mathrm{mg} / \mathrm{L}$ ) are prepared and $2 \mathrm{~g}$ of adsorbent added in all the working samples. The effect of contact 


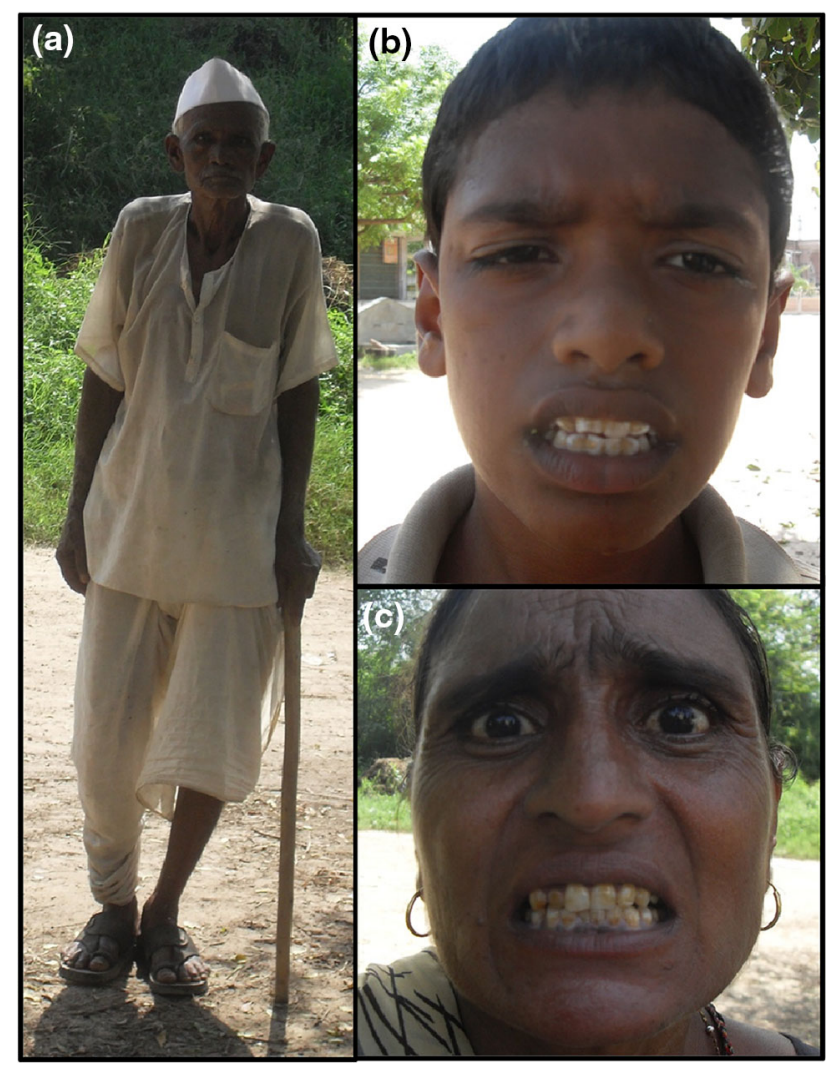

Fig. 2 Different health ailments in the study area related to consumption of fluoride-contaminated water. a Skeletal and b, c dental fluorosis

time between the adsorbent and adsorbate for effective fluoride removal was studied by preparing the samples of known concentration and adding $2 \mathrm{~g}$ of adsorbent and conducts the experiment for same time period. To study the effect of time on fluoride removal, concentration of fluoride was measured at an interval of $1 \mathrm{~h}$ initially up to $8 \mathrm{~h}$, followed by at an interval of $2 \mathrm{~h}$ up to $16 \mathrm{~h}$.

Kinetic studies of sorbent were carried out in a temperature-controlled mechanical shaker. The effect of different initial fluoride concentrations, viz., 2, 4, 6, 8 and $10 \mathrm{mg} / \mathrm{L}$ at $25^{\circ} \mathrm{C}$ temperature on sorption rate, was studied by keeping the mass of sorbent as $2 \mathrm{~g}$ and volume of solution as $50 \mathrm{~mL}$ in neutral $\mathrm{pH}$. The fluoride concentration retained in the adsorbent phase, $q_{\mathrm{e}}(\mathrm{mg} / \mathrm{g})$, was calculated according to Eq. (1):

$q_{\mathrm{e}}=\frac{\left(C_{\mathrm{o}}-C_{\mathrm{e}}\right)}{W}$,

where $q_{\mathrm{e}}$ is the amount of fluoride adsorbed ( $\left.\mathrm{mg} / \mathrm{g}\right) ; C_{\mathrm{o}}$ and $C_{\mathrm{e}}$ are the initial and residual fluoride concentration in solution at equilibrium $(\mathrm{mg} / \mathrm{L})$ respectively; and $W$ is the weight $(\mathrm{g})$ of the adsorbent.

Adsorption equilibrium data were examined with the most widely used being the theoretical Langmuir isotherms model (Langmuir 1916). It is often applied in solid/liquid system to describe the saturated monolayer adsorption well represented by Eq. (2):

$q_{\mathrm{e}}=\frac{q_{\mathrm{m}} K_{\mathrm{a}} C_{\mathrm{e}}}{1+K_{\mathrm{a}} C_{\mathrm{e}}}$,

where $C_{\mathrm{e}}$ is the equilibrium concentration $(\mathrm{mg} / \mathrm{L}) ; q_{\mathrm{e}}$ is the amount of ion adsorbed $(\mathrm{mg} / \mathrm{g}) ; q_{\mathrm{m}}$ is $q_{\mathrm{e}}$ for a complete monolayer $(\mathrm{mg} / \mathrm{g}) ; K_{\mathrm{a}}$ is adsorption equilibrium constant $(\mathrm{L} / \mathrm{mg})$. To evaluate the adsorption capacity for a particular range of adsorbate concentration, the above Eq. (2) can be used in linear form as mentioned by Eq. (3):

$\frac{C_{\mathrm{e}}}{q_{\mathrm{e}}}=\frac{1}{q_{\mathrm{m}}} C_{\mathrm{e}}+\frac{1}{K_{\mathrm{a}} q_{\mathrm{m}}}$.

The constants $q_{\mathrm{m}}$ and $K_{\mathrm{a}}$ can be determined from a linearized form of Eq. (2) by the slope of the linear plot of $C_{\mathrm{e}} / q_{\mathrm{e}}$ versus $C_{\mathrm{e}}$

\section{Results and discussion}

A complete statistics of fluoride distribution pattern in the study area is shown in Table 1. From geochemical analysis of groundwater samples, it is found that fluoride concentration ranges from 0.32 to $4.79 \mathrm{mg} / \mathrm{L}$. More than $70 \%$ of groundwater samples are found with fluoride concentration exceeding from $1.0 \mathrm{mg} / \mathrm{L}$. $\mathrm{pH}$ of the water samples ranges from 7.2 to 7.7 with an average value of 7.4 , indicating that groundwater is slightly alkaline in nature.

\section{Result for fluoride adsorption}

Here in this section, the effect of different parameters on the rate of defluoridation is assessed and described as follows:

Table 1 Statistical analysis of fluoride contamination in groundwater samples for Mehsana District

\begin{tabular}{ll}
\hline Parameters & Values \\
\hline Area in square kilometers & 4393 \\
Population & $18,37,696$ \\
Total number of taluks & 9 \\
Number of fluoride-affected taluks (groundwater & 7 \\
$\quad$ fluoride concentration $>1.0 \mathrm{mg} / \mathrm{L}$ ) & \\
Population of major and minor fluoride-affected blocks & $10,14,857$ \\
Total number of tube well water samples analysed & 34 \\
\% of samples with fluoride $>1.0$ mg/L & 79.73 \\
Fluoride concentration range in groundwater (mg/L) & $0.32-4.79$
\end{tabular}




\section{The effect of adsorbent dose}

To estimate the optimum dose for the effective fluoride adsorption, it is an essential task to find the quantity of adsorbent that is adequate. The experiment to evaluate the effect of dose on adsorption is carried out with an addition of $0.5,1,2,3,4,5$ and $10 \mathrm{~g}$ in the laboratory-prepared sample with an initial concentration of fluoride of $10 \mathrm{mg} / \mathrm{L}$. The result for percentage fluoride adsorption with dose of adsorbents is shown in Fig. 3. It is found that up to a certain extent, with increase in the amount of dose of adsorbent, the percentage of fluoride adsorption also increases. However after that certain amount of dose, no further significant increase in fluoride adsorption is observed. Finally, it is concluded that the lowest quantity of adsorbent required for maximum adsorption was $2 \mathrm{~g}$ of adsorbent per $50 \mathrm{~mL}$ of adsorbate.

\section{Effect of pH}

The effect of $\mathrm{pH}$ on the percentage adsorption of fluoride from the adsorbent surface is estimated by varying the $\mathrm{pH}$ of the working solution from 4 to 8 at an adsorbent dose of $2 \mathrm{~g}$ in $50 \mathrm{~mL}$ of solution with an initial concentration of $10 \mathrm{mg} / \mathrm{L}$. The result for percentage adsorption of fluoride versus $\mathrm{pH}$ of the working solution is shown in Fig. 4. It is found that a higher percentage of fluoride adsorption took place when the $\mathrm{pH}$ is in the acidic range with a maximum absorption at $\mathrm{pH}=4$ (Fig. 4).

\section{Effect of initial concentration}

A given mass of adsorbent can adsorb only a fixed amount of adsorbate, so the initial concentration of the adsorbate solution is very important. The effect of the initial concentration of fluoride in water on the removal of fluoride was studied by varying the initial concentration of fluoride

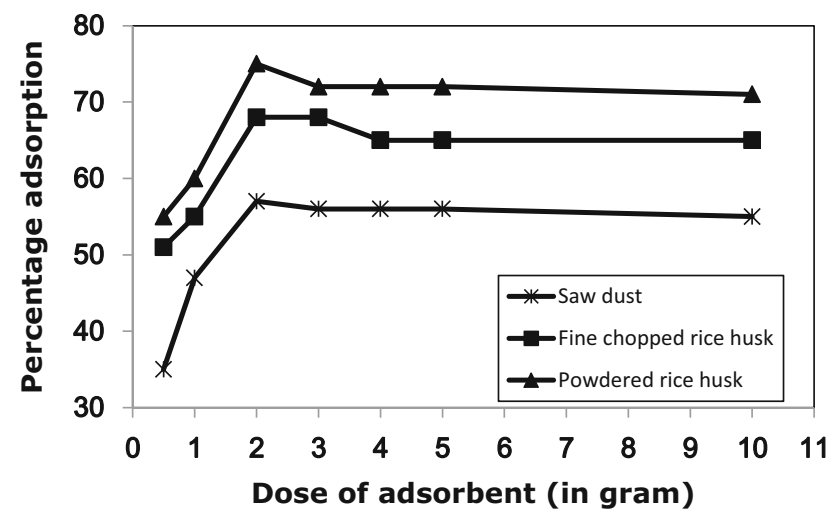

Fig. 3 Scatter plot showing the relation between percentage adsorption of fluoride and dose of adsorbent

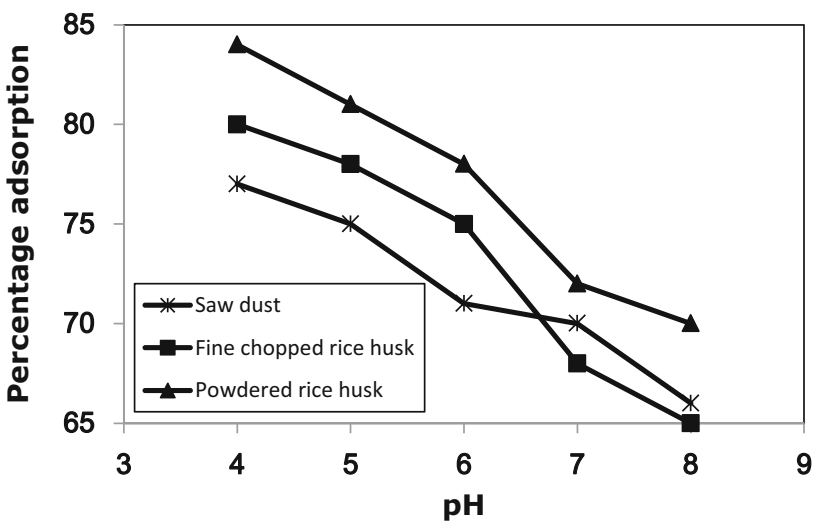

Fig. 4 Scatter plot showing the relation between the percentage adsorption of fluoride and $\mathrm{pH}$ of the working solution

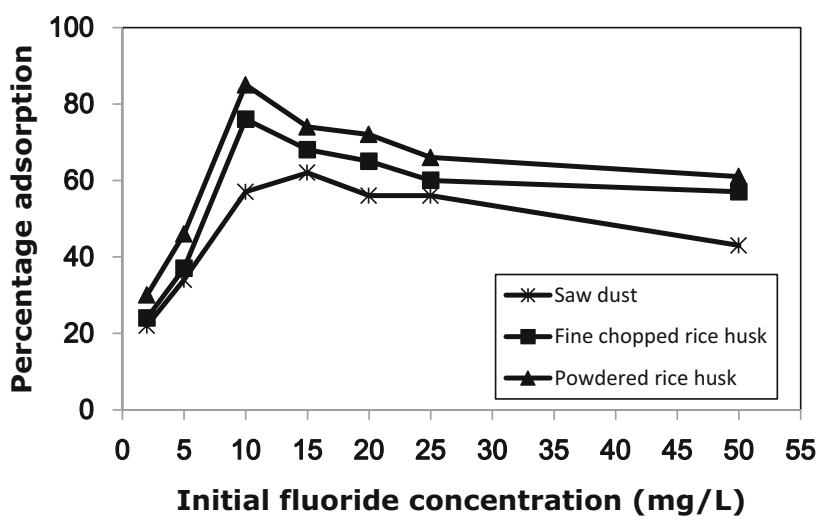

Fig. 5 Scatter plot showing the effect of the initial concentration of fluoride in the sample on percentage adsorption by different adsorbents

from 5 to $50 \mathrm{mg} / \mathrm{L}$, keeping the optimized value of other parameters, viz., dose of adsorbent $2 \mathrm{~g}$ per $50 \mathrm{~mL}$ of solution and $\mathrm{pH}$ at 4 . It is observed that the percentage fluoride removal increases with increase in the initial concentration of the solution, but the efficiency becomes stagnant or even decreases after a certain level. Also, it is clear that the effective percentage removal of fluoride for finely chopped rice husk, powdered rice husk and sawdust takes place at an initial concentration of 10,10 and $15 \mathrm{mg} /$ L, respectively (Fig. 5).

\section{Effect of contact time}

The effect of contact time for the removal of fluoride using finely chopped rice husk, powdered rice husk and sawdust was investigated by analysing the samples collected during treatment at different time intervals. The optimized values of other parameters such as adsorbent dose and $\mathrm{pH}$, as mentioned above, were used. The initial concentration of the synthetic sample was taken as $10 \mathrm{mg} / \mathrm{L}$ and the experiment was done in a temperature-controlled shaker at 


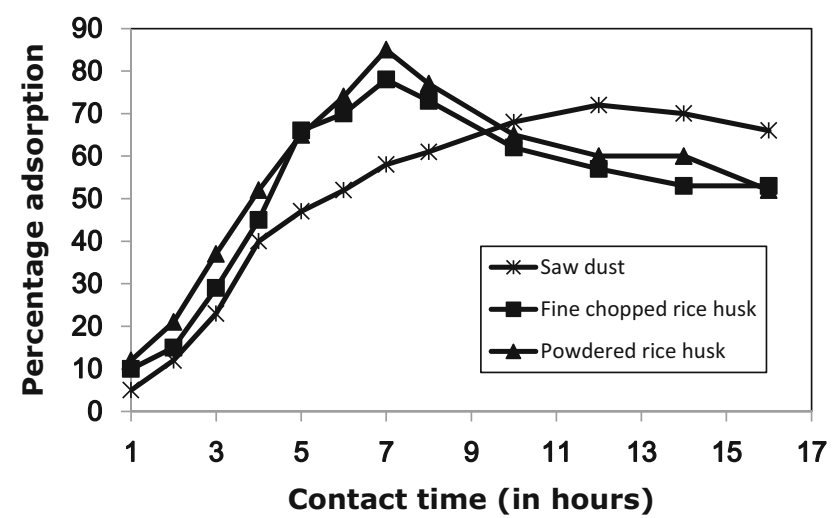

Fig. 6 Scatter plot showing the relation between the percentage adsorption of fluoride and contact time with three different adsorbents

$130 \mathrm{rpm}$ and $25 \pm 2{ }^{\circ} \mathrm{C}$. The results for contact time versus percentage adsorption of fluoride are shown in Fig. 6. Here, it is evident that the rate of fluoride removal increases with time, but after some time reaches the optimum level called saturation condition, beyond which no further adsorption takes place. The experimental value of optimum contact time in case of finely chopped rice husk and powdered rice husk was $7 \mathrm{~h}$, whereas for sawdust the optimum value was $12 \mathrm{~h}$.

\section{Comparative study of defluoridation efficiency using optimized parameters (determined at laboratory scale) versus natural $\mathrm{pH}$ of groundwater sample in the study area}

A comparative study was conducted to assess the defluoridation efficiency of the above optimized parameter (including $\mathrm{pH}$ ) versus optimized parameters (excluding $\mathrm{pH}$ ) using three different natural adsorbents at the field scale. The objective of this experiment was to look for cost minimization using different natural adsorbents. There are three places where we can adjust the cost of defluoridation:

\section{Adsorption dose}

The optimum dose for significant defluoridation for three different adsorbents studied here was $2 \mathrm{~g}$ (Fig. 3). As plenty of all three adsorbents were locally available as well as it is really cheap (ranging from 0.0045 to $0.045 \mathrm{USD} /$ $\mathrm{kg}$ ); so it should not be of major concern.

\section{$p H$}

Optimum $\mathrm{pH}$ for defluoridation using all three adsorbents was $\mathrm{pH}=4$ (Fig. 4), but it was also found that a significant amount of fluoride reduction took place at $\mathrm{pH}=7$. To lower down the $\mathrm{pH}$ of groundwater samples (which are slightly alkaline in nature) to acidic range, a lot of money has to be pumped in the form of different chemicals by the local consumer, which do not appear sustainable or convincing for long periods of time. On the other hand, addition of chemicals to reduce $\mathrm{pH}$ might also alter the water quality, which also raises the question on authentication of this technique.

\section{Contact time}

Although optimum time for significant defluoridation using different adsorbents was different and varied from 7 to $12 \mathrm{~h}$ (Fig. 6), local people over there can perform this experiment for optimum contact time considering the fact that they do not have to pay much extra money for longer period of time. The result of comparative study of field application of all optimized parameters including $\mathrm{pH}$ versus optimized parameters excluding $\mathrm{pH}$ (here $\mathrm{pH} 7$ is considered as natural) using three different natural adsorbents for the selected four water samples from the study area is shown in Fig. 7. Here, it is found that the maximum amount of fluoride adsorption was observed in the case of powdered rice husk followed by fine chopped rice husk and saw dust. Also, it indicates that the difference of fluoride adsorption at different $\mathrm{pH}$ values using other optimized parameters was not significant. Hence, it is wise to apply this methodology for all samples at field scale.

\section{Adsorption isotherms}

The equilibrium data isotherm analysis for fluoride adsorption onto the powdered rice husk at $25{ }^{\circ} \mathrm{C}$ temperature and neutral $\mathrm{pH}$ is shown in Fig. 8. Here, it is found that the adsorbent has a high affinity for fluoride adsorption under the given conditions (with $r^{2}=0.9843$ ). The related parameters obtained by calculation from the values of slopes and intercepts of the linear plot are shown in Table 2. The essential features of the Langmuir isotherm shape can be expressed in terms of a dimensionless constant separation factor or equilibrium parameter $\left(R_{\mathrm{L}}\right)$, indicating whether an adsorption system is favourable or unfavourable, as defined by Eq. 4) Tan et al. (2009):

$R_{\mathrm{L}}=\frac{1}{1+K_{\mathrm{a}} C_{0}}$,

where $R_{\mathrm{L}}$ is a dimensionless separation factor, $C_{0}$ the initial fluoride concentration $(\mathrm{mg} / \mathrm{L})$ and $K_{\mathrm{a}}$ the Langmuir constant ( $\mathrm{L} / \mathrm{mg})$. If the value of $R_{\mathrm{L}}>1$, the isotherm will be unstable; when the value of $R_{\mathrm{L}}=1$, the isotherm will be linear; when the value of $0<R_{\mathrm{L}}<1$, the isotherm will be favourable and when the value of $R_{\mathrm{L}}=0$ the isotherm will be irreversible.

The relationship between $R_{\mathrm{L}}$ and $C_{0}$ to represent the essential features of the Langmuir isotherm for powdered 

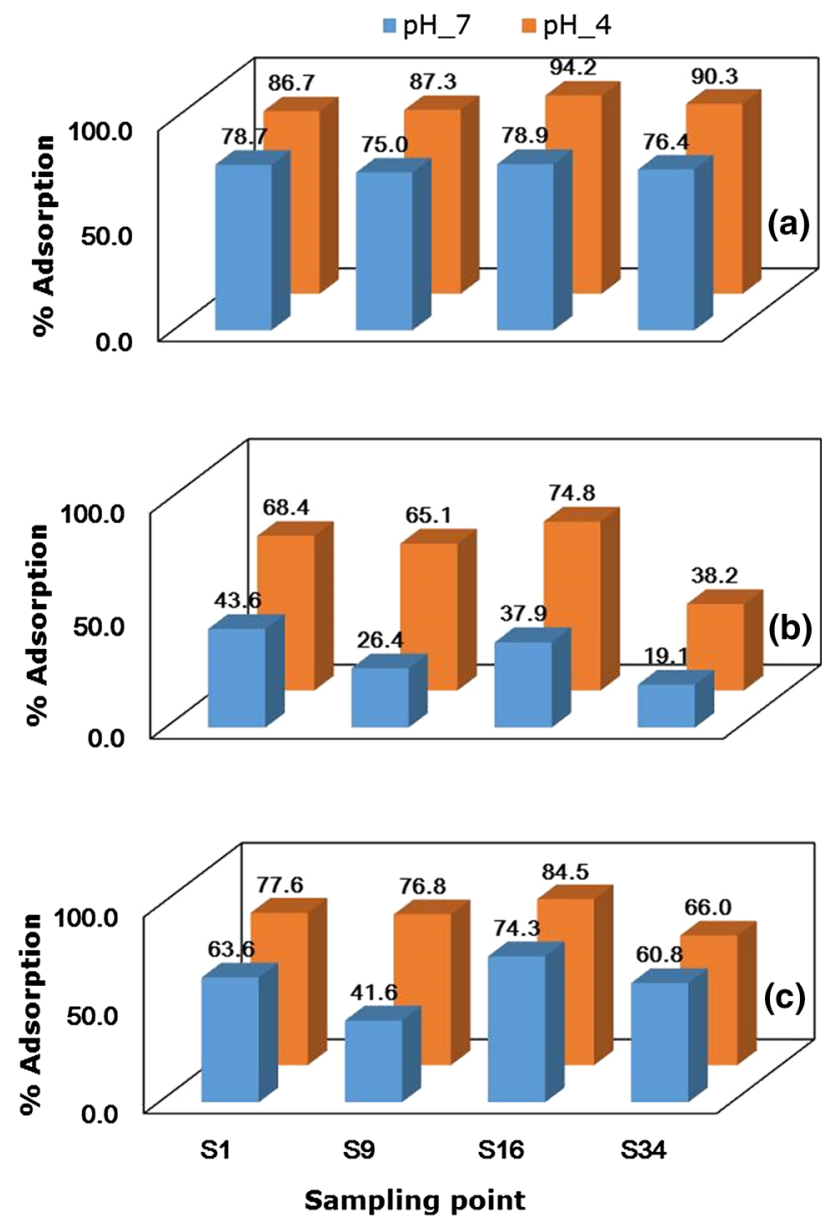

Fig. 7 Comparative assessment for percentage adsorption of fluoride at $\mathrm{pH} 3$ and 7 for selected water samples (keeping optimized value fixed for dose and contact time). a, b, c Results for powdered rice husk, sawdust and finely chopped rice husk, respectively

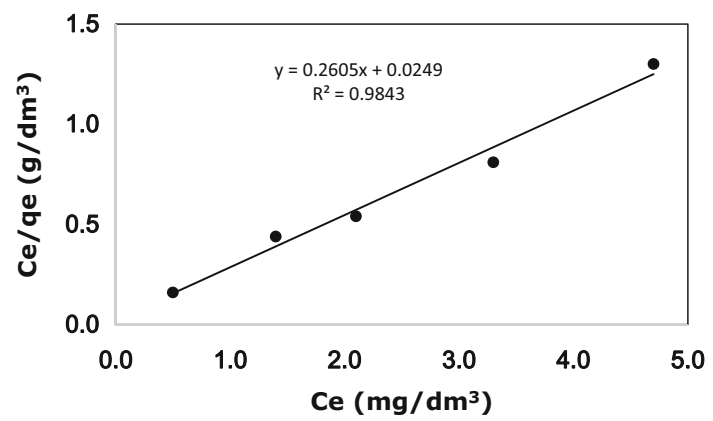

Fig. 8 Langmuir isotherms obtained by using the linear method for the adsorption of fluoride using powdered rice husk at a temperature of $25^{\circ} \mathrm{C}$

rice husk at $25{ }^{\circ} \mathrm{C}$ is shown in Fig. 9. Here, the values of the calculated $R_{\mathrm{L}}$ for the given range of fluoride concentration are found in the range of $0.07-0.31$, which suggests
Table 2 Isotherm parameters obtained using the linear method for the adsorption of fluoride onto using powdered rice husk at a temperature of $25^{\circ} \mathrm{C}$

\begin{tabular}{lc}
\hline Parameters & Value \\
\hline$Q_{\mathrm{m}}(\mathrm{mg} / \mathrm{g})$ & 4.32 \\
$K_{\mathrm{a}}\left(\mathrm{dm}^{3} / \mathrm{mg}\right)$ & 1.97 \\
$R^{2}$ & 0.95 \\
$\mathrm{SSE}$ & 0.02 \\
\hline
\end{tabular}

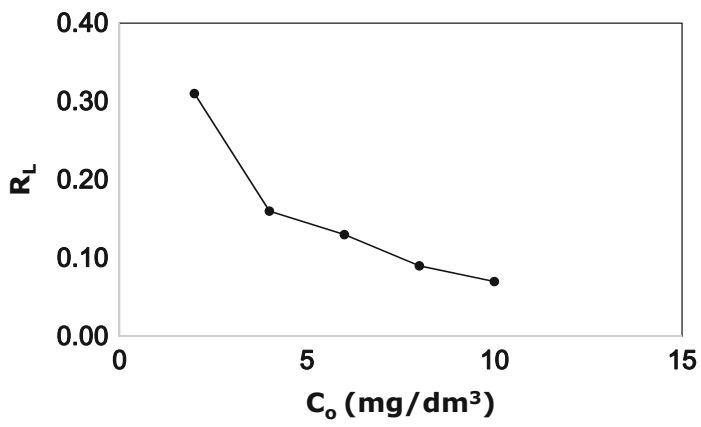

Fig. 9 Plot between separation factor $\left(R_{\mathrm{L}}\right)$ values versus initial fluoride concentration derived by Langmuir constants using powdered rice husk at a temperature of $25{ }^{\circ} \mathrm{C}$

the favourable adsorption of fluoride onto this adsorbent under the conditions used for the experiments.

\section{Effect of temperature on the defluoridation mechanism using rice husk and feasibility of this technique at the ground level}

Gibbs energy $\left(\Delta G^{\circ}\right)$ for the adsorption mechanism can be represented by Eqs. 5 and 6 :

$\Delta G^{\circ}=\Delta H^{\circ}-T \Delta S^{\circ}$,

$\Delta \mathrm{G}^{\circ}=-R T \ln K_{\mathrm{c}}$,

where $T$ is the temperature in ${ }^{\circ} \mathrm{K}, K_{\mathrm{c}}$ the equilibrium constant $\left(q_{\mathrm{e}} / C_{\mathrm{e}}\right)$. Also, it can be represented as a ratio of equilibrium concentration of fluoride attached to rice husk $\left(q_{\mathrm{e}}\right)$ compared to Van't Hoff equation as equilibrium concentration of rice husk in solution $\left(C_{\mathrm{e}}\right)$. Here, the negative value of $\Delta G^{\circ}$ shows the spontaneous feasible nature of the adsorption process. The value of $\Delta H^{\circ}$ and $\Delta S^{\circ}$ can be deduced from the slope and intercept, respectively, of the plot between $\ln K_{\mathrm{c}}$ and $1 / T$. Looking into monthly variation of average minimum and maximum temperature in the study area (Fig. 10), the result for the plot between $\ln K_{\mathrm{c}}$ and $1 / T$ is shown in Fig. 11. Here, the range of the temperature considered is $283-333{ }^{\circ} \mathrm{K}$. It is found that with 


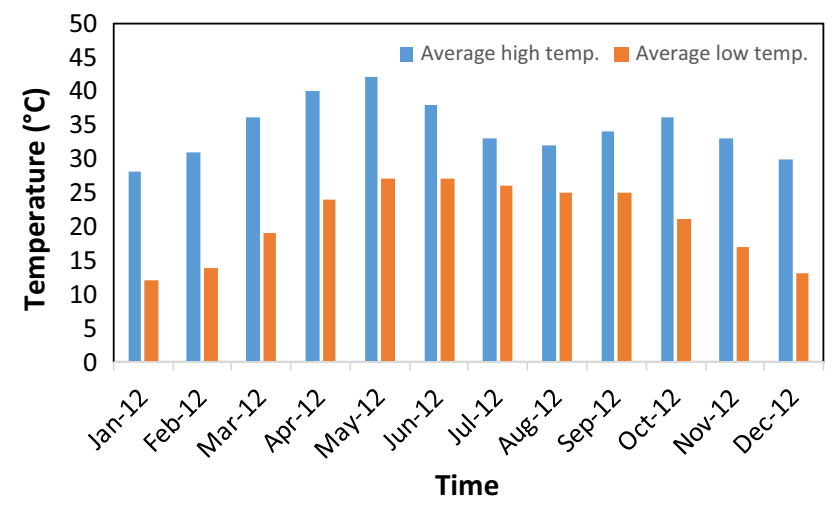

Fig. 10 Variation of monthly average high and low temperature in the study area

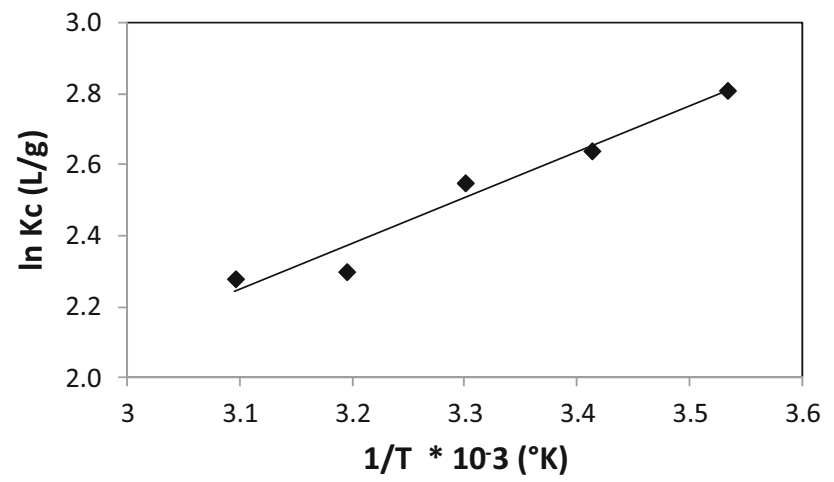

Fig. 11 Scatter plot between $\ln K_{\mathrm{c}}$ and $1 / T$ showing the effect of temperature on fluoride adsorption

increasing temperature, the sorption capacity also increases. Similarly, $\Delta G^{\circ}$ also increases with rising tempertaure.

\section{Application of powdered rice husk for defluoridation at the field scale}

From Fig. 7, it is clear that powdered rice husk shows maximum percentage removal of fluoride among all three natural adsorbents as well as it requires the least time for effective adsorption. Therefore, powdered rice husk was used for adsorption of fluoride from 34 groundwater samples collected from villages of Mehsana District maintaining optimized values of the dose of adsorbent and contact time. The result obtained from the above experiment is given in Fig. 12. Here, it is seen that the percentage of fluoride removal varies from 37.9 to 94.3 with an average value of 68.7 .

Finally, a comparative study shows the different techniques being used for defluoridation and how this study has extended the scientific findings for field application of lowcost adsorbent (Table 3). It is very clear that rice husk is commonly available at very cheap rates, making it a potential candidate for use in future.

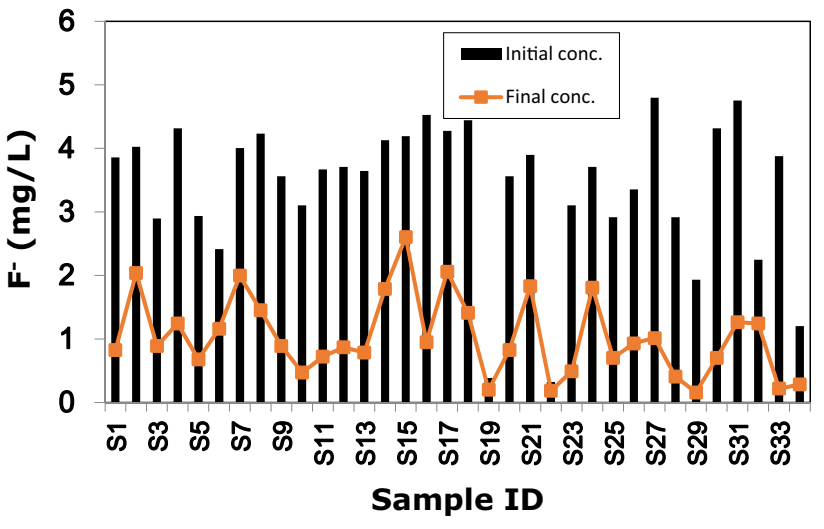

Fig. 12 Status of fluoride concentration in raw water sample (initial concentration) and after being treated with powdered rice husk (final concentration) at natural $\mathrm{pH}$ of water samples. Here, the optimized values for adsorbent dose $(2 \mathrm{~g} / 50 \mathrm{~mL})$ and contact time $(7 \mathrm{~h})$ were considered

\section{Conclusion}

Fluoride pollution in groundwater is a global concern as ingestion of water with fluoride concentration more than $1.5 \mathrm{mg} / \mathrm{L}$ may result in dental or skeletal fluorosis and, in the recent past, the defluoridation from groundwater has become a major thrust area of investigation for the scientific community. There are many defluoridation techniques available in the market such as adsorption (using both natural and artificial adsorbent), reverse osmosis, electrodialysis, ion exchange and membrane filtration. The economic feasibility of different methods has still not been evaluated. This work is an attempt to evaluate the defluoridation efficiency using three newly introduced materials (powdered rice husk, finely chopped rice husk and sawdust) as natural adsorbent based on their availability and economic feasibility. It was found that all the three materials have the property to adsorb the fluoride from groundwater, but the powdered rice husk was most efficient for keeping the optimized value of the dose of the adsorbent and contact time. The $\mathrm{pH}$ is also one of the main factors controlling the adsorption process and the present study compared the performance for different $\mathrm{pH}$ values, i.e. optimized $\mathrm{pH}$ and natural $\mathrm{pH}$ of the groundwater, as adjustment of $\mathrm{pH}$ will not be possible in villages. It is found that powdered rice husk can be efficiently applicable for defluoridation with the natural $\mathrm{pH}$ of groundwater at the field scale. The sorption of fluoride using this adsorbent followed Langmuir isotherms. Finally, for checking the feasibility of powdered rice husk in removing the fluoride from groundwater samples collected from Mehsana District, it was found that it lowers the concentration of fluoride to permissible limit in most of the samples. Thus, it can be concluded that rice husk can be used as a good 
Table 3 Comparative summary of different techniques used for defluoridation

\begin{tabular}{|c|c|c|c|c|}
\hline $\begin{array}{l}\text { S. } \\
\text { no. }\end{array}$ & Defluoridation technique & Removal efficiency & Field application & References \\
\hline 1 & $\begin{array}{l}\text { Coagulation (most common } \\
\left.\mathrm{Al}(\mathrm{OH})_{3}\right)\end{array}$ & Highly efficient & $\begin{array}{l}\text { Commercially available but expensive, } \mathrm{pH} \\
\text { dependent, toxic residual formation }\end{array}$ & Hu et al. (2005) \\
\hline 2 & $\begin{array}{l}\text { Membrane filtration (viz. } \\
\text { reverse osmosis) }\end{array}$ & $\begin{array}{l}\text { Highly efficient, permits } \\
\text { treatment and disinfection } \\
\text { of treated water in a single } \\
\text { step }\end{array}$ & $\begin{array}{l}\text { No chemical added, hence ensuring water quality, } \\
\text { expensive, } \mathrm{pH} \text { correction needed }\end{array}$ & Elazhar et al. (2009) \\
\hline 3 & Ion exchange & $\begin{array}{l}\text { Highly efficient, maintains } \\
\text { taste and colour of treated } \\
\text { water }\end{array}$ & Expensive, resin regeneration is a big hurdle & $\begin{array}{l}\text { Sairam and } \\
\quad \text { Meenakshi (2009) }\end{array}$ \\
\hline 4 & $\begin{array}{l}\text { Adsorption using synthetic } \\
\text { materials (most common is } \\
\text { activated carbon, chitosan) }\end{array}$ & Medium to high efficiency & $\begin{array}{l}\text { Commercially available, residual formation and } \\
\text { with its chemical nature hard to handle, skilled } \\
\text { personnel required for plant operation }\end{array}$ & Ma et al. (2009) \\
\hline 5 & $\begin{array}{l}\text { Adsorption using synthetic and } \\
\text { low-cost natural materials } \\
\text { (like clay muds, shells, husk) }\end{array}$ & Medium to high efficiency & $\begin{array}{l}\text { Locally available material, economically viable, } \\
\text { non-skilled person also can operate (powdered } \\
\text { rice husk has application over a wide range of } \\
\mathrm{pH} \text { as well) }\end{array}$ & $\begin{array}{l}\text { Kemer et al. (2009), } \\
\text { Patel et al. (2014), } \\
\text { Rajkumar et al. } \\
\text { (2015) }\end{array}$ \\
\hline
\end{tabular}

adsorbent for removing the fluoride from groundwater in those area where its contamination is common.

Open Access This article is distributed under the terms of the Creative Commons Attribution 4.0 International License (http:// creativecommons.org/licenses/by/4.0/), which permits unrestricted use, distribution, and reproduction in any medium, provided you give appropriate credit to the original author(s) and the source, provide a link to the Creative Commons license, and indicate if changes were made.

\section{References}

American Public Health Association (APHA) (1995) Standard methods for the examination of water and wastewater, 19th edn. American Public Health Association, Washington, p 1467

Ando M, Tadano M, Yamamoto S, Tamura K, Asanuma S, Watanabe T (2001) Health effects of fluoride pollution caused by coal burning. Sci Total Environ 271:107-116

Avtar R, Kumar P, Surjan A, Gupta LN, Roychowdhury K (2013) Geochemical processes regulating groundwater chemistry with special reference to nitrate and fluoride enrichment in Chatarpur area, Madhya Pradesh, India. Environ Earth Sci 70:1699-1708

Boyle DR, Chagnon M (1995) An incidence of skeletal fluorosis associated with groundwaters of the maritime carboniferous basin, Gaspé region, Quebec, Canada. Environ Geochem Health 17:5-12

Cao J, Zhao Y, Lin JW, Xirao RD, Danzeng SB (2000) Environmental fluoride in Tibet. Environ Res 83:333-337

CGWB (Central Ground Water Board) (2010) Ministry of water resources, Government of India, Ground water quality in shallow aquifers of India, Faridabad. p 117

Chidambaram S, Manikandan S, Ramanathan AL, Prasanna MV, Thivya C, Karmegam U, Thilagavathi R, Rajkumar K (2013) A study on the defluoridation in water by using natural soil. Appl Water Sci. doi:10.1007/s13201-013-0122-1
Chinoy NJ, Narayana MV, Sequeria E, Joshi SM, Barot JM, Purohit RM, Parikh DJ, Ghodasara NB (1992) Studies on effects of fluoride in 36 villages of Mehsana District, North Gujarat. Fluoride 25:101-110

Dhiman SD, Keshari AK (2003) Quantifying uncertainties using fuzzy logic for groundwater driven contaminant exposure assessment. In: Mishra S (ed) Groundwater quality modeling and management under uncertainty. Proceedings of the World Water and Environmental Resources Congress, EWRI-ASCE Publication, Philadelphia, USA, p 236-247

Dutta M, Ray T, Basu JK (2012) Batch adsorption of fluoride ions onto microwave assisted activated carbon derived from Acacia Auriculiformis scrap wood. Arch Appl Sci Res 4:536-550

Elazhar F, Tahaikt M, Achatei A, Elmidaoui F, Taky M, El Hannouni F, Laaziz I, Jarir S, El Amrani M, Elmidaoui A (2009) Economical evaluation of the fluoride removal by nanofiltration. Desalination 249:154-157

Goldman SM, Sievers ML, Templin DW (1991) Radiculomyopathy in a southwestern Indian due to skeletal fluorosis. Ariz Med 28:675-677

Hu CY, Loa SL, Kuan WH (2005) Effects of the molar ratio of hydroxide and fluoride to $\mathrm{Al}(\mathrm{III})$ on fluoride removal by coagulation and electrocoagulation. J Colloid Interface Sci 283:472-476

Ingle NA, Dubey HV, Kaur N, Sharma I (2014) Defluoridation techniques: which on to choose. J Health Res Rev 1(1):1-4

IPCS (1984) Fluorine and fluorides. International Programme on Chemical Safety. Environmental Health Criteria 36, World Health Organization, Geneva, p 180

Jacks G, Bhattacharya P, Chaudhary V, Singh KP (2005) Controls on the genesis of some high-fluoride groundwaters in India. Appl Geochem 20:221-228

Kemer B, Ozdes D, Gundogdu A, Bulut VN, Duran C, Soylak M (2009) Removal of fluoride ions from aqueous solution by waste mud. J Hazard Mater 168:888-894

Keshari AK, Dhiman SD (2001) Genesis of fluoride contamination in the Western Indian Aquifers. In: Ribeiro L (ed) Future groundwater resources at risk (FGR'01), Theme 3: point and non-point source pollution. Proceedings of the Third International Conference, Lisbon, Portugal, pp 1-8 
Kharb P, Susheela AK (1994) Fluoride ingestion in excess and its effect on organic and certain inorganic constituents of soft tissues. Med Sci Res 22:43-44

Kumar P, Kumar A, Singh CK, Saraswat C, Avtar R, Ramanathan AL, Herath S (2016) Hydrogeochemical evolution and appraisal of groundwater quality in Panna District, Central India. Expo Health 8(1):19-30

Langmuir I (1916) The constitution and fundamental properties of solids and liquids. J Am Chem Soc 38:2221-2295

Leung DCW, Hrudey SF (1985) Removal of fluorides from water supplies. Alberta Environmental Standard and Approval Division, July 1985, p 107

Ma Y, Wang SG, Fan M, Xin WX, Gao BY (2009) Characteristics and defluoridation performance of granular activated carbons coated with manganese oxides. J Hazard Mater 168:1140-1146

Malakootian M, Moosazadeh M, Yousefi N, Fatehizadeh A (2011) Fluoride removal from aqueous solution by pumice: case study on Kuhbonan water. Afr J Environ Sci Technol 5:299-306

Meenakshi, Maheshwari RC (2006) Fluoride in drinking water and its removal. J Hazard Mater B137:456-463

Mondal NC, Prasad RK, Saxena VK, Singh Y, Singh VS (2009) Appraisal of highly fluoride zones in groundwater of Kurmapalli watershed, Nalgonda district, Andhra Pradesh (India). Environ Earth Sci 59:63-73

Patel SC, Khalkho R, Patel SK, Sheikh JM, Behera D, Chaudhari S, Prabhakar N (2014) Fluoride contamination of groundwater in parts of eastern India and a preliminary experimental study of fluoride adsorption by natural haematite iron ore and synthetic magnetite. Environ Earth Sci 72:2033-2049
Rajkumar S, Murugesh S, Sivasankar V, Darchen A, Msagati TAM, Chaabane T (2015) Low-cost fluoride adsorbent prepared from a renewable biowaste: syntheses, characterization and modeling studies. Arab J Chem. doi:10.1016/j.arabjc.2015.06.028

Razbe N, Kumar R, Pratima Kumar R (2006) Removal of fluoride ion from aqueous solution. Int J Comput Eng Res 3(4):128-133

Sairam SC, Meenakshi S (2009) Fluoride sorption using organicinorganic hybrid type ion exchangers. J Colloid Interface Sci 333:58-62

Sajidu S, Kayira C, Masamba W, Mwatseteza J (2012) Defluoridation of groundwater using raw bauxite: rural domestic defluoridation technology. Environ Nat Resour Res 2:1-9

Singh CK, Kumari R, Singh RP, Shashtri S, Kamal V, Mukherjee S (2011) Geochemical Modeling of high fluoride concentration in groundwater of Pokharan area of Rajasthan, India. Bull Environ Contam Toxicol 86:152-158

Tan IAW, Ahmad AL, Hameed BH (2009) Adsorption isotherms, kinetics, thermodynamics and desorption studies of 2,4,6trichlorophenol on oil palm empty fruit bunch-based activated carbon. J Hazard Mater 164:473-482

Togarepi E, Mahamadi C, Mangombe A (2012) Deflouridation of water using physico-chemically treated sand as a low-cost adsorbent: an equilibrium study. Afr J Environ Sci Technol 6:176-181

WHO (World Health Organization) (1984) Guidelines for drinking water quality, vol II: health criteria and supporting information. World Health Organization, Geneva, p 548 